\title{
Income Inequality in Latin America and Eastern EU through the Great Recession: An Ordered Probit Analysis
}

\author{
Peter Mikek ${ }^{*}$, Adam Carter \\ Department of Economics, Wabash College, USA
}

Copyright $\bigcirc 2017$ by authors, all rights reserved. Authors agree that this article remains permanently open access under the terms of the Creative Commons Attribution License 4.0 International License

\begin{abstract}
Income distribution directly affects economic growth and the spending patterns in an economy. This paper employs an ordered probit panel to measure the effect of the Great Recession on income inequality in Latin American and Eastern EU members. The results suggest the crisis increased inequality in studied countries overall. However, those countries with low levels of inequality saw their Gini coefficients decrease further, while the crisis increased inequality in countries with already high inequality. Additionally, the results show that European Union membership on average contributed to lower likelihood of high Gini coefficients. Furthermore, marginal effects lend additional evidence of lower income gap for the Eastern EU members as they generally show negative marginal effects for countries with initially high inequality and positive for those with low Gini coefficients. Finally, we find no evidence that FDI and capital incentives have any direct impact on inequality, while GDP growth, poverty, and export incentives are associated with higher and tax revenues and export growth with lower income inequality.
\end{abstract}

Keywords Income Inequality, Financial Crisis, Poverty, Great Recession

\section{Introduction}

Income inequality across the globe is high with Gini indices between 55 and 70 and it has been increasing in advanced economies (Piketty and Saez [1]), reaching 37.2 for the US and 35.5 for UK in 2012 (Dabla-Norris et al. [2]). However, it is developing economies that are facing the most serious challenges of income inequality (for example, Gini index for Brazil is 46.3). In addition to considering some level of economic equality a social value, the widening of income and wealth gap brings about serious economic costs since it reduces economic growth (Ostry, Berg, and Tsangarides [3]; Berg and Ostry [4]) through various channels. High inequality can be detrimental for socio-economic stability and harms investment activity and therefore economic growth (Alessina and Perotti [5]). Furthermore, concentration of savings in top of the distribution is associated with financial deepening and transferring these assets to the rest of population through credits. Since these are less stable this could contribute to likelihood of financial crisis (Goda et al. [6]) closing the feedback from inequality to crisis and to growth. Moreover, inequality lowers the capacity of middle and lower income households to contribute to capital accumulation and investment in human capital lowering productivity and long term growth. Finally, inequality affects the spending patterns as rich likely have lower marginal propensity to spend then less fortunate that affect aggregate demand.

Even with the recent trend of decreasing income inequality, Latin America remains the regions with the most unequal distribution of income in the world (Tsounta and Osueke [7]), with Gini index of 44.22 (as opposed to 42 for Sub-Saharan Africa and 30 for Europe - Dabla-Norris et al. [2]). This has slowed economic growth in the region and widened the gap between developed nations and most Latin America's countries (Lopez and Perry [8]). Similarly, compared to the rest of the $\mathrm{EU}$, income inequality is relatively high in its Eastern European members with "Eastern Europe experiencing marked increases in inequality" (Dabla-Norris et al. [2]; Baiardi and Morana [9]). Both regions are in proximity of wealthy neighbors and have developed strong trade and economic ties with them. Thus, we examine the factors that contribute to income inequality in Latin America and compare them to some Eastern European members of the EU.

This paper contributes to the existing literature on income inequality along several dimensions. While building on Chen and Tsai [10], we depart from them in several important ways by asking a different question, concentrate on the Great Recession (after 2007), formally test for the effect of the financial crisis and substantially expand and improve the focus of the data set.

We investigate the span of 22 years and pay special attention to the Great Recession that had strong effects on economic performance and income around the globe. We posit that the financial and economic crisis worsened income 
inequality as it denied easy access to credit to particularly financially weak economic agents and therefore caused substantial increase in unemployment and restructuring of job opportunities. Additionally, Chen and Tsai [10] fail to formally test whether the effect of Asian crisis was statistically significant. We directly include financial crisis and can thus easily perform such test in the ordered probit panel estimation.

We also examine if the membership in the EU helped the Eastern European countries coping with financial difficulties and therefore resulted in smaller impact of the crisis on income inequality. Furthermore, we simultaneously narrow the focus on the set of countries in Latin America and Eastern European EU members and substantially expand the number of countries included in the analysis to 27 . Rich countries (such as OECD members) exhibit different characteristics concerning income inequality (E.g. Cingano [11]; Hellenbrandt [12]; Dabla-Norris et al. [2]; Chintrakarn et al. [13]). Thus, our focus improves homogeneity of the group by excluding some substantially different countries, such as the rich ones. Finally, we substantially expanded and revised data on both export incentives and capital incentives $(1 / 3$ of countries in the sample).

More widespread data on inequality in Latin America became available in the 1990s, when a number of countries began taking consistent household surveys (Gasparini et al. [14]). We saw inequality rise in most Latin American countries during 1990s. However, in the early 2000s the region experienced a decreasing trend in inequality with generally dropping Gini coefficients. Lustig [15] concluded that the trend was due to increased minimum wages and unionization of labor, shifts in demand for and supply of skilled vs. unskilled labor, and direct government transfer programs, i.e. welfare support programs, in the three largest Latin American economies: Argentina, Brazil, and Mexico. Even with the fall of Gini coefficients in most of Latin America, income inequality as "a distinctive, pervasive characteristic of the region" is still very high compared to the rest of the world (Gasparini and Lustig [16]).

In addition to high levels of income inequality most of Latin American countries exhibit also high levels of poverty. Thus, solid economic growth becomes an imperative for economic and political stability of these countries. However, through instilling higher levels of socio-political instability and thus economic uncertainty, income inequality harms investment activity. This further shows in a worse economic growth (Dabla-Norris et al. [2]) and is detrimental for poverty levels, closing the vicious cycle. While the situation in Eastern European EU members is far less severe they do share some similar challenges. Baiardi and Morana [9] report that they found worsening of income gap in all euro area countries during the crisis and add that the peripheral countries, including most of eastern EU members, were "most strongly hit."

Thus, our main question inquires what the impact of the Great Recession on income inequality in these two regions was. Additionally, we are interested in other contributing factors, including globalization, the difference between Eastern EU members and Latin America and export and capital incentives.

To preview the results, they show overall increasing income inequality as a result of financial crisis. Countries with high initial inequality see further increases through crisis years. This was mitigated for the EU members, supporting views of their comparative convergence. Export growth contributed to decreasing income inequality. Poverty, export incentives and economic growth are associated with deterioration of income inequality. Finally, we found no effect of FDI and capital incentives, and only marginal (albeit significant) influence of exchange rate and income per capita on income inequality levels in these two regions.

The next section provides a brief overview of related literature. The third section describes the methodology and data. The fourth section presents the results while the last section draws conclusions.

\section{Literature Review}

Studies of inequality typically focus on advanced economies (e.g. Cingano [11]; Hellenbrandt [12]; Chintrakarn et al. [13]; Figini and Goerg [17]) or frequently included the effect of fast growing China and India. However, the dynamics of income inequality in advanced economies is substantially different than in developing countries (Dabla-Norris et al. [2]) that are focus of our study and, in general, differ from Chinese or Indian record.

The nexus between inequality and economic growth commands the central stage. As we indicated in the outset the inequality is detrimental for growth ${ }^{1}$. However, there are also numerous studies that found negative effect of growth on inequality (e.g. Ostry, Berg, and Tsangarides [3]; Dabla-Noris et al. [2]). Growth is driven by technological change. As Dabla-Norris et al. [2] point out growth has been "accompanied by skill-biased technological change." Acemoglu [18] and Card and DiNardo [19] conclude that technological changes cause elimination of low-skill jobs due to automation and create jobs that require additional skills (and frequently training). This increases the skill premium and exacerbates inequality. Furthermore, several of these countries pursued growth through substantial liberalization in search of flexibility on job markets. Dabla-Norris et al. [2] report that easing labor market regulations contributes to wage gap. Thus, while growth is an imperative for climbing out of poverty for many countries it also means higher income inequality. Many authors (e.g. Kuznets [20]; Tsounta and Osueke [7]; Mah [21]) suggest

1 "If the income share of the top 20 percent increases by 1 percentage point, GDP growth is actually 0.08 percentage point lower in the following five years, suggesting that the benefits do not trickle down. Instead, a similar increase in the income share of the bottom 20 percent (the poor) is associated with 0.38 percentage point higher growth." [2] 
that there exists a Kuznets curve indicating that with growth income distribution first worsens before it improves at higher levels of income. Thus, income gap directly depends on income level. Celic and Basdas [25], however, report contrasting results of the effect of GNI per capita on income inequality.

Ravallion [26], Nijhawan and Dubas [27] and Chen and Tsai [10] all found negative correlation between poverty and income inequality. The conclusion seems to be robust with respect of using either dummy variables or a share of population below poverty line ( $2 \$$ per day is common) to measure poverty. Most studies, however, examine the connection through the effects of growth. Dabla-Norris et al. [2] use female mortality as a proxy for poverty and find it to be significant determinant of the Gini coefficient.

The literature is unclear on the effects of globalization on income inequality as it operates through a variety of channels. Barro [28] finds that an increase in trade increases inequality. Several studies, including Baten and Fraumholz [29], Ravallion [30], and Freeman [31] find that increased openness leads to increased inequality in a country. Dabla-Norris et al. [2] find no significant effect of trade openness, but report significant effect of financial openness. Bogliaccini [32] claims that international liberalization in Latin America is associated with deindustrialization which worsens inequality. However, Dollar and Kraay [33] find that openness leads to faster growth and a reduction of poverty and, thus, lower inequality. Chen and Tsai's [10] conclude that export and capital incentives were a key strategy for attracting FDI and report that export incentives had a large, positive effect on inequality.

The results are conflicting also for the effect of FDI on inequality. Hoi and Pomfret [34], Mah [35] and Choi [36] find that FDI increase country's income gap. Similarly, Figini and Goerg [17] claim that there is "a nonlinear effect in developing countries: wage inequality increases with FDI inward stock, with such effect diminishing with further increases in FDI." Also Basu [37] and Chintrakarn et al. [13] report the negative effect of FDI on income inequality, while Feenstra and Hanson [38] suggest that inflow of FDI leads to higher skill premium widening the gap. However, for Latin America, Tsounta and Ouseke [7] reported that stronger FDI actually contributes to lower income inequality in LA.

Focusing on exchange rates, Sylwester [39] claims that high variability of the real exchange rate is usually a symptom of an unstable economy that is likely associated with higher inequality. Chen and Tsai [10] find their results confirming the claim; however, the magnitude of their coefficients is minute, albeit significant.

Many studies include fiscal variables to study the effect of redistribution through fiscal policy on income inequality. Dabla-Norris et al. [2] find government spending to be significant determinant of Gini coefficient. However, Joumard et al. [40] Pirtilla and Tuomala [41], and Tsounta and Ouseke [7] use tax revenues. Cignano [11] reports that the redistribution through taxes is "key tool to insure the benefits of growth are more broadly distributed." Similarly, Hellenbrandt [12] argues that "changes in direct taxes have counteracted the increase in income disparities." Pirttilla and Tuomala [41] find that a relatively lower tax rate leads to a reduction in poverty levels. Tsounta and Ouseke [7] claim that higher tax revenues are important contributor to recent reduction in income inequality in Latin America. Moreover, Acosta-Ormaechea et al. [42] find that inequality is not affected by the growth-friendly fiscal reforms. Finally, Chen and Tsai [10] report capital incentives don't significantly contribute to Gini coefficient.

There is mixed evidence on the role of financial deepening. Dabla-Norris et al. [2] reported that "financial deepening is associated with rising inequality" in emerging markets and developing economies. They postulated that this is due to relatively low level of financial inclusion and concentrating benefits of financial deepening in small groups. However, they admit that there are large disparities in the use of financial services between advanced economies and the rest. In contrast, a number of studies show that financial deepening reduces income inequality: among others Meyer Bittencourt [43] for Brazil, Shabaz et al. [44] for Iran, Shabaz and Islam [45] for Pakistan, and Ang [46] for India. The apparent contradiction is likely due to existence of the financial Kuznets curve (Sahay et al. [21]; Baiardi and Morana [21]; Mandel [47]). They all find that income inequality decreases as financial deepening raises up to a threshold value, but after that further growth in financial deepening increases income gap.

Gasparini and Cruces [48] argued that the recent decreases in inequality in Latin America have been due to improved public policy and positive trends in trade in the region. Similarly, Lustig [15] pointed that there have been an increase and an improvement in government transfer programs in Latin America. Also Tsounta and Ouseke [7] and Dabla-Norris et al. [2] reported that more education spending was the most important drive in declining income gap in Latin America. However, they still emphasize that countries in Latin America had higher levels of inequality than their counterparts around the world.

\section{Data}

Our sample includes data on 27 countries, 17 from Latin America and 10 from Eastern Europe ${ }^{2}$. Unfortunately, we had to drop Cuba, Haiti, and Nicaragua due to limited data on Gini coefficients. Our time period spans over a 22 year, from 1990 to $2012^{3}$, which covers the Great Recession and therefore allows for direct testing of its effects on income

\footnotetext{
2 Eastern Europe: Poland, Czech Republic, Slovakia, Hungary, Slovenia, Estonia, Latvia, Lithuania, Romania, Croatia. Latin America: Argentina, Bolivia, Brazil, Chile, Colombia, Costa Rica, Dominican Republic, Ecuador, El Salvador, Guatemala, Honduras, Mexico, Panama, Paraguay, Peru, Uruguay, Venezuela.

3 Notice that the period excludes the time of recent serious economic and political crisis in Venezuela.
} 
inequality in these two regions. All 10 of the Eastern European countries joined the European Union at some point during the period which will facilitate testing for the effect of $\mathrm{EU}$ on income inequality in the newcomers.

Since we extracted data for Gini indices from the World Development Indicators (WDI), our focus methodologically corresponds to theirs. Thus, we focus on after tax consumption based Gini indices. The World Bank constructs the indices based on national surveys, therefore, there may be some variability in the manner they are collected. However, where possible they adjust for known differences. Additionally, variability in disposable income based information is larger than that of the consumption based inequality information. Therefore, the World Bank uses the consumption based data in construction of the Gini index or, alternatively when this is not possible, adjusts the information to correspond to the one based on consumption expenditure ${ }^{4}$.

We approach the analysis by categorizing Gini indices ${ }^{5}$ into $4(\mathrm{k}=0,1,2,3)$ ordered categories (following [10]) as follows:

$$
\begin{array}{|l|l|}
0 & \text { if } 0<\text { Gini } \leq 35 \\
\hline 1 \text { if } 35<\text { Gini } \leq 45 \\
\hline 2 \text { if } 45<\text { Gini } \leq 55 \\
\hline 3 \text { if Gini }>55
\end{array}
$$

Such approach allows for possibility that inequality at different levels implies different behavior of agents and therefore different marginal effects (as clearly identified below). Thus, the assumption of OLS that considers unchanged reaction at different levels of regressors is not warranted. Additionally, we test to see if the cut-off points are significant and the groups definable. Furthermore, Chen and Tsai find them "appropriate."

To gain further insight, we applied an ordered probit model for pooled data based on McKelvey and Zavoina [49]. Adjusted for our specific purpose of explaining determinants of Gini coefficients, the latent regression can be specified as follows (Green [50]):

$$
\begin{gathered}
\operatorname{Gini}^{*}{ }_{\text {it }}=\alpha+\beta^{\prime} X_{\mathrm{it}}+\varepsilon_{\mathrm{it}} \\
\operatorname{Gini}_{\mathrm{it}}=0 \text { if Gini }{ }_{\mathrm{it}} \leq \delta_{0} \\
\operatorname{Gini}_{\mathrm{it}}=1 \text { if } \delta_{0}<\mathrm{Gini}^{*}{ }_{\mathrm{it}} \leq \delta_{1} \\
\operatorname{Gini}_{\mathrm{it}}=\mathrm{k} \quad \text { if } \delta_{\mathrm{k}-1}<\text { Gini }{ }_{\mathrm{it}}
\end{gathered}
$$

Where Gini $_{\mathrm{it}}$ is an approximation of the underlying actual Gini coefficient (that is indicated by $*$ ), $\varepsilon_{\text {it }}$ is standard normal error term and $\delta_{\mathrm{k}-1}(\mathrm{k}=1,2,3)$ are unknown threshold parameters that are, along with $\beta_{\mathrm{k}}$, estimated by maximum likelihood.

4 Further methodological details can be found at http://iresearch. worldbank.org/PovcalNet/index.htm or http://databank. worldbank.org/data/reports.aspx?source=world-developme nt-indicators\#

5 Interpreted as the usual aggregation of the departures from the Lorenz curve (Lorenz [21]; Gini [22]).
Assuming four categories and therefore three underlying cut points to be estimated we can estimate the probability function of $\mathrm{Gini}_{\mathrm{it}}$ as follows:

$$
\begin{gathered}
\operatorname{Prob}\left(\operatorname{Gini}_{\mathrm{it}}=0\right)=\mathrm{F}\left(-\operatorname{Gini}_{\mathrm{it}}{ }^{*}\right) \\
\operatorname{Prob}\left(\operatorname{Gini}_{\mathrm{it}}=1\right)=\mathrm{F}\left(\delta_{1}-\operatorname{Gini}_{\mathrm{it}}{ }^{*}\right)-\mathrm{F}\left(-\operatorname{Gini}_{\mathrm{it}}{ }^{*}\right) \\
\operatorname{Prob}\left(\operatorname{Gini}_{\mathrm{it}}=2\right)=\mathrm{F}\left(\delta_{2}-\operatorname{Gini}_{\mathrm{it}}{ }^{*}\right)-\mathrm{F}\left(\delta_{1}-\operatorname{Gini}_{\mathrm{it}}{ }^{*}\right) \\
\operatorname{Prob}\left(\operatorname{Gini}_{\mathrm{it}}=3\right)=1-\mathrm{F}\left(\delta_{2}-\operatorname{Gini}_{\mathrm{it}}{ }^{*}\right)
\end{gathered}
$$

Where $\delta_{\mathrm{k}-1}$ is estimated cut points for each category of the Gini coefficient and $\mathrm{F}$ is the cumulative standard normal distribution. This allows for subsequent recovery of the marginal effects as in Greene [50]. As Becker and Kennedy [51] point out, increasing value for $X$ while keeping cut points and $\beta$ unchanged, shifts the probability distribution (direction depends on the sign of the coefficients). If we postulate a positive sign for a coefficient $\beta$, an increase in the regressor will shift the probability distribution to the right and therefore unequivocally imply a positive marginal effect for the highest group and negative for the lowest group. However, the marginal effects for Gini $=1$ and Gini=2 are unclear and depend on the "shape of the density as well as the magnitude" of the estimated coefficient.

Given specification above, we estimate the ordered probit panel based on the following underlying model:

$$
\begin{gathered}
\text { Gini }_{\mathrm{it}}{ }^{*}=\mathrm{b}_{0 \mathrm{i}}+\mathrm{b}_{1} \text { GDPGrowth }_{\mathrm{it}}+\mathrm{b}_{2} \text { GNIPC }_{\mathrm{it}}+\mathrm{b}_{3} \text { Poverty }_{\mathrm{it}}+\mathrm{b}_{4} \\
\text { FDIPC }_{\mathrm{it}}+\mathrm{b}_{5} \text { ExportGrowt }_{\mathrm{it}}+\mathrm{b}_{6} \text { FER }_{\mathrm{it}}+\mathrm{b}_{7} \text { EIDummy }_{\mathrm{it}}+ \\
\mathrm{b}_{8} \text { TaxRevenue }_{\mathrm{it}}+\mathrm{b}_{9} \text { CIDummy }_{\mathrm{it}}+ \\
+\mathrm{b}_{10} \text { EUDummy }_{\mathrm{it}}+\mathrm{b}_{11} \text { CrisisDummy }_{\mathrm{it}}+\mathrm{u}_{\mathrm{it}}
\end{gathered}
$$

$i=1, \ldots, \mathrm{N}=27$, indicates individual country,

$t=1, \ldots, \mathrm{T}=22$, indicates the time period,

$u$ is the normally distributed disturbance term and $b_{0}$ the constant. Table 1A in the Appendix provides description of variables and Table 2A gives their descriptive statistics. Table 3A in the appendix provides "raw" Gini indices for four representative years. Availability of data dictated the structure of this unbalanced ordered probit panel.

Along with a number of studies mentioned above, we expect to find economic growth in our sample widening income gap. Several studies above indicated existence of Kuznets curve we include income per person as a measure of the level of economic development. In this study, poverty is defined as the percent of a population in a given country living on less than $\$ 2$ a day. Countries with a higher level of poverty have been found to have high levels of income inequality leading us to expect a positive coefficient on poverty.

As discussed above, previous research provides a mixed guidance as to what to expect in terms of FDI or exports, while suggesting stable exchange rate to be inequality improving. However, export incentives are likely to contribute to both exports and attracting FDI and through their effect on skill premium likely worsening income inequality. In line with the literature, we expect positive coefficients on tax revenues and capital incentives. Finally, 
we postulate that EU membership has be income inequality reducing for its Eastern European members.

Unlike previous literature, we included the crisis dummy to examine the effect of the Great Recession on income inequality. For example, we expand upon Chen and Tsai [10] that provided some tentative evidence of the effects of Asian financial crisis, but failed to formally test for changes. Our specification, however, does allow for simple formal test of the crisis effect. We suspect that the results will be driven by the differences in financial development in different countries and the financial Kuznets curve. In line with the literature discussed above, we postulate that economic crisis most strongly affected the low skill workers from the bottom of the income distribution across all countries in our sample. However, this was likely mitigated by the substantial drop of income for people (directly or indirectly) related to financial industry. Thus, the expected effect of crisis on income gap would be its widening for countries with relatively less developed financial industry, in accordance with the financial Kuznets curve. However, the effect will depend on how pervasive were the connections of the rest of the economy with financial industry. Thus, for countries with relatively deep financial sector the effect may be ambiguous.

\section{Results}

\section{A. Estimates}

The results of the estimation are given in Table 1. It is notable that the cut points are significant which means that the proposed Gini groupings are identifiable and maybe even appropriate. Similarly, Chi squared tests for the null $\mathrm{H}_{0}: \beta_{\mathrm{k}}=$ 0 are also highly significant, lending additional support for the model specification. Finally, we report the McFadden pseudo $\mathrm{R}^{2}$.

Table 1. Empirical results of ordered probit

\begin{tabular}{|c|c|c|c|c|c|c|}
\hline & Model 1 & Model 2 & Model 3 & Model 4 & Model 5 & Model 6 \\
\hline Crisis Dummy & & & & $\begin{array}{l}.444 * * \\
(2.27)\end{array}$ & $\begin{array}{c}.773 * * * \\
(5.00)\end{array}$ & $\begin{array}{l}.478^{* *} \\
(2.56)\end{array}$ \\
\hline Poverty & & & $\begin{array}{c}.100 * * * \\
(8.23)\end{array}$ & & & $\begin{array}{c}.099 * * * \\
(8.26)\end{array}$ \\
\hline EU Dummy & $\begin{array}{c}-1.238^{* * *} \\
(-5.30) \\
\end{array}$ & $\begin{array}{c}-619^{* * *} \\
(-3.23) \\
\end{array}$ & & $\begin{array}{c}-1.344 * * * \\
(-5.58) \\
\end{array}$ & $\begin{array}{c}-637 * * * \\
(-3.13) \\
\end{array}$ & \\
\hline GDP Growth & $\begin{array}{l}.035^{* *} \\
(2.34)\end{array}$ & & & $\begin{array}{l}.038 * * \\
(2.59) \\
\end{array}$ & & \\
\hline GNIPC & & $\begin{array}{c}-.000 * * * \\
(-6.80)\end{array}$ & $\begin{array}{c}-.000 \\
(-0.56)\end{array}$ & & $\begin{array}{c}-.000 * * * \\
(-8.06)\end{array}$ & $\begin{array}{c}-.000 \\
(1.38)\end{array}$ \\
\hline FER & & $\begin{array}{l}.000 * * \\
(2.11)\end{array}$ & & & $\begin{array}{l}.000 * * \\
(2.10)\end{array}$ & \\
\hline FDIPC & & $\begin{array}{c}-.000 \\
(-0.32) \\
\end{array}$ & & & $\begin{array}{c}-.000 \\
(-0.67) \\
\end{array}$ & \\
\hline Export Growth & $\begin{array}{l}-.020^{* *} \\
(-2.16) \\
\end{array}$ & $\begin{array}{l}.015^{* *} \\
(-2.09) \\
\end{array}$ & $\begin{array}{l}-.008 \\
(-0.87) \\
\end{array}$ & $\begin{array}{l}.015^{*} \\
(-1.65) \\
\end{array}$ & $\begin{array}{l}-.010 \\
(-1.42) \\
\end{array}$ & $\begin{array}{c}-.004 \\
(-0.35) \\
\end{array}$ \\
\hline EI Dummy & $\begin{array}{c}1.188^{* * *} \\
(6.39) \\
\end{array}$ & & $\begin{array}{c}1.440 * * * \\
(8.44)\end{array}$ & $\begin{array}{c}1.198^{* * *} \\
(6.50)\end{array}$ & & $\begin{array}{c}1.467 * * * \\
(8.57)\end{array}$ \\
\hline CI Dummy & $\begin{array}{c}-.048 \\
(-0.31)\end{array}$ & & & $\begin{array}{l}-.060 \\
(-.39)\end{array}$ & & \\
\hline Tax Revenue & $\begin{array}{c}-.147^{* * *} \\
(-7.23) \\
\end{array}$ & & & $\begin{array}{c}-.148^{* * * *} \\
(-7.31) \\
\end{array}$ & & \\
\hline Cut 1 & $\begin{array}{c}-2.699 * * * \\
(-7.285) \\
\end{array}$ & $\begin{array}{c}-1.585^{* * *} \\
(-11.484) \\
\end{array}$ & $\begin{array}{c}.437 \\
(1.626)\end{array}$ & $\begin{array}{c}-2.655^{* * * *} \\
(7.225) \\
\end{array}$ & $\begin{array}{c}-1.635^{* * *} \\
(11.923)\end{array}$ & $\begin{array}{c}.401 \\
(1.494)\end{array}$ \\
\hline Cut 2 & $\begin{array}{c}-1.680^{* * *} \\
(-4.700) \\
\end{array}$ & $\begin{array}{c}-1.109^{* * *} \\
(-8.904)\end{array}$ & $\begin{array}{c}1.228 * * * \\
(4.237)\end{array}$ & $\begin{array}{c}-1.616^{* * *} \\
(4.585) \\
\end{array}$ & $\begin{array}{c}-1.145^{* * *} \\
(9.330)\end{array}$ & $\begin{array}{c}1.216^{* * *} \\
(4.198) \\
\end{array}$ \\
\hline Cut 3 & $\begin{array}{l}.110 \\
(.294)\end{array}$ & $\begin{array}{l}.337 * * * \\
(2.883) \\
\end{array}$ & $\begin{array}{c}3.696 * * * \\
(9.884) \\
\end{array}$ & $\begin{array}{c}.030 \\
(.082) \\
\end{array}$ & $\begin{array}{l}.332 * * * \\
(2.849)\end{array}$ & $\begin{array}{c}3.702 * * * \\
(9.832) \\
\end{array}$ \\
\hline $\mathrm{Chi}^{2}$ & 274.92 & 147.02 & 221.38 & 271.29 & 174.25 & 227.98 \\
\hline P-Value & 0.000 & 0.000 & 0.000 & 0.000 & 0.000 & 0.000 \\
\hline Psuedo $\mathrm{R}^{2}$ & 0.276 & 0.111 & 0.379 & 0.281 & 0.124 & 0.385 \\
\hline
\end{tabular}


We will first focus on the effects of the Great Recession and then comment on the other results. Our central question was to investigate whether the economic and financial crisis exacerbated the income disparities in both studied regions. The coefficient on dummy for Great Recession (Crisis Dummy) is clearly significant across different model specifications. Furthermore, the estimates indicate the likelihood of a country having higher income inequality in general substantially increased during the crisis. While Chen and Tsai [10] failed to formally test the difference between pre- and post-crisis estimates, the results of our test to some extend corroborate their untested contention. They claimed that the 1997 Asian financial crisis that poorer countries were more likely to face higher inequality levels afterwards. While we consider a different sample, we similarly find higher inequality due to the crisis. This seems to suggest that the effects of the crisis on different social segments and particularly on different skill groups were likely asymmetric. Similarly to Gasparini and Lustig [16] and Dabla-Norris et al. [2], we conjecture that the crisis particularly affected middle and low income groups because of (a) lack of labor institutions, (b) deregulation, and (c) restricting their access to financial services.

As Table $2 \mathrm{~A}$ in appendix shows, poverty afflicts up to about $26 \%$ of people in most countries in the sample, however it reaches even to roughly $65 \%$ in the poorest country in our sample. Our estimates for poverty align well with the literature (e.g. Ravallion [26]; Nijhawan and Dubas [27]; Chen and Tsai [10]) and clearly indicate that poverty is significant and increases the likelihood of high Gini coefficients.

The dummy for Central and Eastern European countries captures the Eastern European EU members. It is highly significant over different specifications and indicates lower income inequality in the Eastern EU as compared to the Latin America. While Dabla-Norris et al. [2] report widening income gap in Eastern EU, the income inequality there is still significantly lower than the one in Latin America.

The estimates suggest that our measure of income inequality increases as the GDP growth is higher. This is in line with Dabla-Norris et al. [2] who point out that along with financial deepening it is technological progress that largely explains the widening income gap. The mechanics is based on technological improvements that are the basis for growth but at the same time increase the skill premium. In contrast, however, the GNI per person is associated with lower Gini coefficients, which is consistent with our expectations and literature.

Our trade variables include exchange rate, export growth, and a dummy for export incentives. Similarly to some previous studies (Chen and Tsai [10]), we find that exchange rate has significant but extremely small magnitude effect on income inequality. Export growth, however, in general reduces the income disparities as it likely reflects productivity (and therefore income) gains in exporting countries. Additional effect likely comes from the fact that a lot of exports from these countries are concentrated in low skill industries. On average, almost $2 / 3$ of the countries in the sample use some kind of export incentives (Table $2 \mathrm{~A}$ in the appendix). In contrast with export growth, the export incentives contribute to widening the income gap. In general, the results roughly align with findings of Barro [28], Chen and Tsai [10] and Dabla-Norris et al. [2].

FDI per person show no significant effect on Gini coefficient. This is both similar to previous studies (e.g. Mah [22]) and puzzling. One would expect that FDI bring along new technological solutions and easier access to foreign markets. Thus, FDI require more high-skilled labor and the skill premium drives to higher income inequality. For example, Mah [46] finds that "income inequality worsens with FDI flows into China." We suspect that the impact of FDI is to certain extent diluted by the strong effect of export incentives, as shown by the statistically insignificant coefficient in the regression. In contrast to Mah [22] who finds no such effect, Tsai and Chen [10] find that FDI lower Gini coefficient, however, only for a sub-period. We wonder if this is not sample specific and not a general phenomenon.

Just over $70 \%$ of countries in our sample offer some capital incentives (Table 2A in the appendix). Consistent with literature (Chen and Tsai [10]), we also find that among fiscal variables capital incentives are not significant. However, tax revenues as a share of GDP are highly significant and they decrease the likelihood of having higher Gini group. This is roughly in line with literature (e.g. Jaumard et al. [40]) that, in general, finds that redistribution of income through fiscal policy reduces income inequality.

To summarize, we find that economic crisis and poverty, along with GDP growth and export incentives, increase the likelihood of higher income inequality in a country. In contrast, level of GNI per person, export growth, tax revenues, and membership in the EU reduce the likelihood of high Gini coefficient.

\section{B. Marginal Effects}

To provide further insights into the results, we use marginal effects that are provided in Table 2. As expected, the signs of marginal effects for the probability of Gini=3 correspond to the signs of the coefficients, while those of Gini $=0$ are opposite. 
Table 2. Marginal effects for ordered probit

\begin{tabular}{|c|c|c|c|c|c|c|c|c|c|c|c|c|}
\hline & \multicolumn{4}{|c|}{ Model 1} & \multicolumn{4}{|c|}{ Model 2} & \multicolumn{4}{|c|}{ Model 3} \\
\hline & Gini $=0$ & Gini $=1$ & Gini $=2$ & Gini $=3$ & Gini $=0$ & Gini $=1$ & Gini $=2$ & Gini $=3$ & Gini $=0$ & Gini $=1$ & Gini $=2$ & Gini $=\mathbf{3}$ \\
\hline \multicolumn{13}{|l|}{ CrisisDummy } \\
\hline Powerty & & & & & & & & & $-0.185^{* * *}$ & $-0.223^{* * *}$ & $0.247^{* * *}$ & $0.160^{* * *}$ \\
\hline EUDummy & $0.414^{* * * *}$ & 0.000 & $-0.345 * * *$ & $-.069 * * *$ & $0.211^{* * * *}$ & 0.031**** & $-0.146 * * *$ & $-0.096^{* * *}$ & & & & \\
\hline GDPGrowth & $-0.009^{* *}$ & $-0.005^{* *}$ & $0.010 * *$ & $0.003^{* *}$ & & & & & & & & \\
\hline GNIPC & & & & & $0.000^{* * *}$ & $0.000^{* * *}$ & -0.000 & $-0.000^{* * *}$ & 0.000 & 0.000 & -0.000 & -0.000 \\
\hline FER & & & & & $-0.000^{* *}$ & $-0.000^{* *}$ & $0.000^{* *}$ & $0.000^{* *}$ & & & & \\
\hline FDIPC & & & & & -0.000 & 0.000 & 0.000 & 0.000 & & & & \\
\hline ExportGrowth & $0.005^{* *}$ & $0.003^{* *}$ & $-0.006^{* *}$ & $-0.002^{* *}$ & $0.004^{* *}$ & $0.002^{*}$ & $-0.003^{* *}$ & $-0.003^{* *}$ & 0.001 & 0.001 & 0.001 & -0.001 \\
\hline EIDummy & $-0.333^{* * *}$ & $-0.106^{* * *}$ & $0.329^{* * *}$ & $0.110^{* * *}$ & & & & & $-0.007^{* * *}$ & $-0.016^{* * *}$ & $0.009^{* * *}$ & $0.014 * * *$ \\
\hline CIDummy & 0.012 & 0.007 & -0.014 & -0.005 & & & & & & & & \\
\hline \multirow[t]{3}{*}{ TaxRevernse } & $0.038^{* * * *}$ & $0.020^{* * * *}$ & $-0.044^{* * * *}$ & $-0.015 * * *$ & & & & & & & & \\
\hline & \multicolumn{4}{|c|}{ Model 4} & \multicolumn{4}{|c|}{ Model 5} & \multicolumn{4}{|c|}{ Model 6} \\
\hline & Gini $=0$ & Gini $=1$ & Gini $=2$ & Gini $=3$ & Gini $=0$ & Gini $=1$ & Gini $=2$ & Gini $=3$ & Gini $=0$ & Gini $=1$ & Gini $=2$ & Gini $=3$ \\
\hline CrisisDummy & $-0.097 * * *$ & $-0.078^{*}$ & $0.119^{* *}$ & $0.056^{*}$ & $-0.166^{* * *}$ & $-0.083^{* * *}$ & $0.037^{*}$ & $0.213^{* * *}$ & $-0.025 * *$ & $-0.066^{* * *}$ & -0.006 & $0.085 * *$ \\
\hline Powerty & & & & & & & & & $-0.007^{* * *}$ & $-0.016 * * *$ & $0.009^{* * *}$ & $0.014 * * *$ \\
\hline EUDummy & $0.449^{* * *}$ & -0.010 & $-0.369^{* * *}$ & $-0.070^{* * *}$ & $0.216 * * *$ & $0.033^{* * *}$ & $-0.155^{* * *}$ & $-0.094^{* * *}$ & & & & \\
\hline GDPGrowth & $-0.010^{* *}$ & $-0.005^{* *}$ & $0.011^{* *}$ & $0.004^{* *}$ & & & & & & & & \\
\hline GNIPC & & & & & $0.000^{* * *}$ & $0.000^{* * *}$ & $-0.000^{* * *}$ & $-0.000^{* * *}$ & 0.000 & 0.000 & -0.000 & -0.000 \\
\hline FER & & & & & $-0.000^{* *}$ & $-0.000^{* *}$ & $0.000^{* *}$ & $0.000^{* *}$ & & & & \\
\hline FDIPC & & & & & -0.000 & -0.000 & -0.000 & $0.000^{* * *}$ & & & & \\
\hline ExportGrowth & 0.004 & 0.002 & -0.005 & -0.001 & 0.003 & 0.001 & -0.002 & -0.002 & 0.000 & 0.001 & -0.000 & -0.001 \\
\hline EIDummy & $-0.332^{* * *}$ & $-0.110^{* * *}$ & $0.335^{* * *}$ & $0.108^{* * *}$ & & & & & $-0.183^{* * *}$ & $-0.231^{* * *}$ & $-0.254^{* * *}$ & $0.160^{* * *}$ \\
\hline CIDummy & 0.015 & 0.009 & -0.018 & -0.006 & & & & & & & & \\
\hline TaxRevernse & $0.038^{* * *}$ & $0.021^{* * *}$ & $-0.045 * * *$ & $-0.014 * * *$ & & & & & & & & \\
\hline
\end{tabular}

Highlighting our main result, we will focus first on the estimates for the crisis in the lower part of the table. Estimates for financial and economic crisis are significant for almost all models. They indicate that crisis worsened income inequality. In particular, it was associated with a reduction of the likelihood of wide income gap even in the countries with relatively low initial Gini coefficients. In contrast, the crisis further exacerbated the likelihood of strong income inequality for countries that already had substantial income gap.

However, estimates for export growth and tax revenue are significant and they suggest closing income gap by decreasing the likelihood of low Gini coefficients for countries with less inequality and the opposite decreasing likelihood of high Gini coefficients for countries with higher inequality. This is consistent with expectations as fiscal policy is instrumental in redistribution market incomes. Not surprisingly, the estimates of marginal effects are significant and consistently seem to suggest the EU membership is associated with smaller income gap for the EU members. This confirms the numerous findings of lower income disparities in Europe than in Latin America. While, the capital incentive marginal effects estimates are not significant, also at the margin, the foreign exchange has significant and but very small effect.

In contrast and consistent with expectations, export incentives, GDP growth, and poverty show marginal effects, similar to those of the crisis, indicating deterioration of the income inequality. Furthermore, poverty shows an increase in income gap as the countries with large poor population are less efficient in reducing the inequality. Thus, a country with Gini equal to 3 experiences higher likelihood of being in that group if poor. Similarly, the likelihood of having Gini=2 is higher for poor (and just the opposite for countries that are not poor).

To sum up, the marginal effects further corroborate the results above highlighting the deteriorating effect of the crisis on income equality in studied countries. Similarly, economic growth, export incentives, and poverty contribute to widening income gap. However, export growth, tax revenues, and membership in the EU seems to exhibit reducing effect on income inequality.

\section{Conclusions}

We used an ordered probit panel to examine the effect of the Great Recession on income inequality in Latin American and Eastern EU members. Estimation results indicated an increase in the likelihood of having high income inequality due to the crisis and seem to suggest widening of the income distribution.

We offer two complementary explanations. First, the crises in the past (Gasparini and Lustig [16]) disproportionately hit low and middle income household due to lack of safety nets, weak labor institutions and market oriented deregulation (Mandel [47]). This was also the case of the Great Recession that disproportionately affected middle and low income groups widening income gap.

Second, literature surveyed above reports of financial 
deepening as an inequality reducing factor (e.g. Meyer Bittencourt [43] or Shabaz [44]). Additionally, most of the countries in our sample are likely on the lower spectrum of the financial Kuznets curve (Baiardi and Morana [9]; Sahay et al. [21]; Mandel [47]). Moreover, while lack of financial knowledge, cumbersome processes, availability and costs of financial products (Dabla-Norris et al. [2]) weigh heavily against middle and low income groups in "normal times", the crisis exacerbated the situation even further. This means that financial crisis that brought about substantial reduction in financial deepening exacerbated the income gap by particularly restricting access of middle and low income groups to financial services.

Additionally, the results show that European Union membership on average contributed to lower likelihood of high Gini coefficients. Finally, we find no evidence that FDI and capital incentives have any direct impact on inequality. This is surprising since we expected that FDI would bring better technologies and therefore increasing the skill premium for workers. We suspect that this is due to its interaction with other openness variables.

While GDP growth, poverty, and export incentives are associated with higher income inequality, tax revenues and export growth reduce income inequality. The results for poverty and GDP growth are roughly in line with literature. It comes as no surprise that the tax variable clearly exibits benefits of redistribution for income inequality. Export growth is probably concentrated in low skill industries in these developing countries and is therefore inequality improving.

In conclusion, wide income disparities in Latin America and Eastern Europe were additionally strongly and negatively affected by the Great Recession. The results suggest that further analysis is needed to clearly determine the channels through which FDI and other measures of openness along with financial variables and labor institutions affect income inequality.

\section{Appendix}

Table 1A. Variable Description

\begin{tabular}{|c|c|}
\hline GDP Growth & Growth rate of GDP for a country \\
\hline FDIPC & Net inflows of foreign direct investment per person \\
\hline GNIPC & Gross National Production per person \\
\hline Export Growth & Growth rate of total exports of goods and services \\
\hline FER & Average official exchange rate in local currency for 1 USD \\
\hline Poverty & Share of population living under 2\$ per day \\
\hline Tax Revenue & Tax revenue as a share of total GDP \\
\hline EI Dummy & Export Incentives offered \\
\hline CI Dummy & Capital Incentives offered \\
\hline EU Dummy & EU membership \\
\hline Crisis Dummy & Time period after 2007 \\
\hline
\end{tabular}

Table 2A. Descriptive Statistics

\begin{tabular}{|c|c|c|c|c|c|}
\hline Variable & Obs & Mean & SD & Min & Max \\
\hline Gini & 499 & 1.469 & 1.059 & 0 & 3 \\
\hline GDP Growth & 604 & 3.277 & 4.761 & -32.119 & 78.287 \\
\hline FDIPC & 602 & 233.333 & 514.466 & -2093.35 & 7470.674 \\
\hline GNIPC & 604 & 5381.708 & 4426.597 & 556.088 & 26255.88 \\
\hline Export Growth & 607 & 6.202 & 8.774 & -23.495 & 45.853 \\
\hline FER & 587 & 618.078 & 2870.959 & 0.000 & 25000 \\
\hline Poverty & 322 & 14.146 & 12.291 & 0 & 64.95 \\
\hline Tax Revenue & 366 & 15.318 & 3.698 & 6.765 & 26.872 \\
\hline EI Dummy & 621 & 0.630 & 0.483 & 0 & 1 \\
\hline CI Dummy & 621 & 0.701 & 0.457 & 0 & 1 \\
\hline EU Dummy & 621 & 0.126 & 0.332 & 0 & 1 \\
\hline Crisis Dummy & 621 & 0.217 & 0.413 & 0 & 1 \\
\hline
\end{tabular}


Table 3A. Gini Indices for Selected Years

\begin{tabular}{|c|c|c|c|c|c|}
\hline Country & Code & 1998 & 2002 & 2006 & 2011 \\
\hline Argentina & ARG & 51 & 54 & 48 & 44 \\
\hline Bolivia** & BOL & 58 & 60 & 56 & 46 \\
\hline Brazil & BRA & 60 & 59 & 57 & 53 \\
\hline Chile* & $\mathrm{CHL}$ & 56 & 55 & 52 & 51 \\
\hline Colombia & $\mathrm{COL}$ & 59 & 61 & 59 & 54 \\
\hline Costa Rica & CRI & 46 & 51 & 49 & 49 \\
\hline Dominican Rep.*** & DOM & 52 & 50 & 52 & 47 \\
\hline Ecuador* & ECU & 47 & 55 & 53 & 46 \\
\hline El Salvador & SLV & 55 & 53 & 46 & 42 \\
\hline Guatemala & GTM & 56 & 59 & 56 & 52 \\
\hline Honduras & HND & 57 & 59 & 58 & 57 \\
\hline Mexico & MEX & 49 & 50 & 48 & - \\
\hline Panama & PAN & 58 & 57 & 55 & 52 \\
\hline Paraguay & PRY & 57 & 57 & 55 & 53 \\
\hline Peru & PER & 56 & 56 & 51 & 45 \\
\hline Uruguay & URY & 44 & 47 & 47 & 43 \\
\hline Venezuela & VEN & 50 & 51 & 47 & - \\
\hline Average & & 53 & 55 & 52 & 49 \\
\hline Croatia & CRO & 40 & 41 & 41 & 41 \\
\hline Czechia & CZE & 30 & 30 & 30 & 30 \\
\hline Estonia & EST & 38 & 36 & 34 & 33 \\
\hline Hungary & HUN & 26 & 27 & 28 & 29 \\
\hline Latvia & LAT & 33 & 35 & 36 & 36 \\
\hline Lithuania & LIT & 32 & 32 & 34 & 33 \\
\hline Poland & POL & 33 & 34 & 35 & 33 \\
\hline Romania & ROM & 31 & 30 & 30 & 35 \\
\hline Slovakia & SLK & 36 & 37 & 38 & 27 \\
\hline Slovenia & SLN & 28 & 30 & 25 & 25 \\
\hline Average & & 33 & 33 & 33 & 32 \\
\hline
\end{tabular}

* for $2003, * *$ for $1999, * * *$ for 2000

\section{REFERENCES}

[1] T. Piketty, E. Saez. Income inequality in the United States 1913-1998, Quarterly Journal of Economics, Vol. 118, 1-39, 2011.

[2] E. Dabla-Norris, K. Kochhar, N. Sphaphiphat, F. Ricka, E. Tsounta. Causes and consequences of income inequality: A global perspective, IMF staff discussion note 15/13, 2015.

[3] J.D. Ostry, A. Berg, C. Tsangarides. Redistribution inequality, and growth, IMF Staff Discussion Note 14/02, 2014.

[4] A. Berg, J.D. Ostry. Inequality and the unsustainable Growth:

Two sides of the same coin? IMF Staff Discussion Note 11/08, 2011.

[5] A. Alesina, R. Perotti. Income distribution, political instability, and investment, European Economic Review, Vol. 40, 1203-1228, 1996.

[6] T. Goda, O. Onaran, E. Stockhammer. Income and wealth concentration in the recent financial crisis, Development and Change, Vol. 48, 3-27, 2017.

[7] E. Tsounta. A. Osueke. What is behind Latin America's declining income inequality? IMF Working Paper no. 14/124, 2014.

[8] J.H. Lopez, G. Perry. Inequality in Latin America: Determinants and consequences, Policy Research Working Paper 4504, The World Bank, 2008. 
[9] D. Baiardi, C. Morana. Financial deepening and income distribution inequality in the euro area, The Rimini center for economic analysis working paper 15-44, 2015.

[10] J.H. Chen, W.C. Tsai. A comparison of international income inequality: an ordered probit model analysis, Applied Economics, Vol. 44, 1701-1716, 2012.

[11] F. Cingano. Trends in income inequality and its impact on economic growth, OECD Social, Employment and Migration Working Papers no. 163, 2014.

[12] T. Hellenbrandt. Income inequality developments in the Great Recession, Peterson Institute for International Economics Policy Brief 14-3, 2014.

[13] P. Chintrakarn, D. Herzer, P. Nunnenkamp. FDI and income inequality: evidence from a panel of U.S. states, Economic Inquiry, Vol. 50, 788-801, 2012.

[14] L. Gasparini, G. Cruces, L. Tornarolli. Recent trends in income inequality in Latin America, Economia, Spring, $147-190,2011$.

[15] N. Lustig. Latin America's inequality success story, Current History, Vol. 112, 64-69, 2013.

[16] L. Gasparini, N. Lustig. The rise and fall of income inequality in Latin America, Society for the Study of Economic Inequality Working Paper no. 2011-213, 2011.

[17] P. Figini, H. Goerg. Does foreign direct investment affect wage inequality? An empirical investigation, The World Economy, Vol. 34, 1455-1475, 2011

[18] D. Acemoglu. Why do new technologies complement skills? Directed technical change and wage inequality, Quarterly Journal of Economics Vol. 113, 1055-1089, 1998.

[19] d. Card, J. E. DiNardo. Skill biased technological change and rising wage inequality: Some problems and puzzles, NBER Working Paper 8769, NBER, 2002.

[20] S. Kuznets. Economic growth and income inequality, The American Economic Review, Vol. 45, 1-28, 1955.

[21] R. Sahay, M. Cihak, P. N'Diaye, A. Brajas, R. Bi, D. Ayala, Y. Gao, A. Kyobe, L. Nguyen, C. Saborowski, K. Svirydzenska, S.R. Yousefi. Rethinking financial deepening: Stability and growth in emerging markets, IMF staff discussion note 15/08, 2015.

[22] Mah, J. S. (2003) A note on globalization and income distribution - the case of Korea, 1975 -1995, Journal of Asian economics, $14,157-164$

[23] M. O. Lorenz. Methods of measuring the concentration of wealth, Publications of the American Statistical Association, Vol .9, 209-219, 1905.

[24] C. Gini. Variabilitá e mutabilitá: Contributo allo studio delle distribuzioni e delle relazioni statistiche, Studi Economico-giuridici della Regia Facoltà Giurisprudenza, Vol. 3, 3-159, 1912.

[25] S. Celik, U. Basdas. How does globalization affect Income Inequality? A Panel data analysis, Int Adv Econ Res, Vol. 16, 358-370. 2010

[26] M. Ravallion. Can high-inequality developing countries escape absolute poverty? Economic Letters, Vol. 56, 51-57
1997.

[27] I. P. Nijhawan, K. Dubas. A reassessment of the relationship between income inequality and poverty, Journal of Economics and Economic Education Research, Vol. 7, 103-115, 2006.

[28] R. J. Barro. Inequality and growth in a panel of countries, Journal of Economic Growth, Vol. 5, 5-32, 2000.

[29] J. Baten, U. Fraunholz. Did partial globalization increase inequality? The case of the Latin American periphery, 1950-2000, CESifo Economic Studies, Vol. 50 45-84, 2004.

[30] M. Ravallion. Growth, inequality, and poverty: look beyond averages, World Development, Vol. 29, 1803-1815. 2001.

[31] R. Freeman. Does inequality increase economic output? In Controversies about inequality, Stanford University Press, 2010

[32] J. A. Bogliaccini. Trade liberalization, deindustrialization, and inequality: Evidence from middle-income Latin American countries, Latin American Research Review, Vol. 48, 79-105, 2013.

[33] D. Dollar, A. Kraay. Trade, growth, and poverty, The Economic Journal, Vol. 114, 22-49, 2004

[34] Q. Hoi Le, R. Pomfret. Technology spillovers from foreign direct investment in Vietnam: horizontal or vertical spillovers? Journal of the Asia Pacific Economy, Vol. 16, 183-201, 2011.

[35] J.S. Mah. Foreign direct investment, labour, unionization and income inequality of Korea, Applied Economics Letters, Vol. $19,1521-1524,2012$

[36] C. Choi. Does foreign direct investment affect domestic income inequality? Applied Economics Letters, Vol. 13, 811-814, 2006.

[37] P. Basu, A. Guariglia. Foreign Direct Investment, inequality and growth, Journal of Macroeconomics, Vol. 29, 824-839, 2007.

[38] R.C. Feenstra, G. Hanson. Foreign direct investment and relative wages: evidence from Mexico's Maquiladoras, Journal of Economic Economics, Vol. 42, 371-393, 1997.

[39] K. Slywester. A note of geography, institutions, and income inequality, Economic Letters, Vol. 85, 235-240, 2004.

[40] I. Joumard, M. Pisu, D. Bloch. Tackling income inequality: The role of taxes and transfers, OECD Journal: Economic Studies, Vol. 2, 37-70, 2012.

[41] H. Pirttila, M. Tuomala. Poverty alleviation and tax policy, European Economic Review, Vol. 48, 1075-1090, 2004.

[42] S. Acosta-Ormaechea, T. Komatsuzaki, D. Correa-Caro. Fiscal reforms, long-term growth and income inequality, IMF Working Paper 17/145, 2017.

[43] M. F. Meyer Bittencourt. Financial development and inequality: Brazil, SSRN Electronic Journal 12/2006, 2006.

[44] M. Shahbaz, N. Loganathan, A. Kumar, R. Sherafatian-Jahromi. Financial development and income inequality: Is there any financial Kurznets curve in Iran? Social Indicators Research, 2014.

[45] M. Shabaz, F. Islam. Financial development and income inequality in Pakistan: An application of ARDL approach, 
Journal of economic development, Vol. 36, 35-53, 2011.

[46] J. B. Ang. Financial liberalization and income inequality, Southern Economic Journal, Vol. 76, 738-761. 2010.

[47] B. Mandel.) Dependencia revisited: Financial liberalization and inequality in Latin America, The Michigan Journal of Business, 57-96, 2009.

[48] L. Gasparini, G. Cruces. Poverty and inequality in Latin America: A story of two decades, Journal of International Affairs, Vol. 66, 51-63, 2013.
[49] R. McKelvey, W. Zavoina. A Statistical model for the analysis of ordinal level dependent variables, Journal of Mathematical Sociology, Vol. 4, 103-120, 1975.

[50] W. H. Greene. Econometric Analysis, Macmillan Publishing, New York, 1993.

[51] W. E. Becker, P .E. Kennedy. A graphical exposition of the ordered probit, Econometric Theory, Vol. 8, 127-131, 1992.

[52] J. S. Mah. The effects of foreign direct investment inflows on income inequality: Evidence from China, Global Economy Journal, Vol. 15, 443-453, 2015. 